\title{
Pertanggung Jawaban Pers \\ Terhadap Kebebasan Pers
}

\section{Susilawati, S.H., M. Hum.}

(Staf Pengajar FH UISU)

\begin{abstract}
Abstrak
Seiring dengan lahirnya UU No. 40 Tahun 1999 Tentang Pers, kebebasan pers seperti kebablasan, undang-undang pers dianggap undang-undang yang paling bebas di dunia. Sehingga wartawan merasa dirinya paling hebat, paling benar, dan paling dibutuhkan negara. Tanggung jawab pers merupakan kewajiban moral pers dalam melakukan fungsinya sebagai media informasi.
\end{abstract}

Kata Kunci : Pers, Tanggung jawab pers. 


\section{A. Latar Belakang}

Thomas Jefferson, presiden ke3 AS, berkata, "If I were to choose between having a government without news papers or news papers without government, I would undoubtedly choose the latter." Begitu pentingnya pers bagi rakyat sehingga dia memilih pers tanpa pemerintah daripada pemerintah tanpa pers.

Dalam menjalankan tugasnya pers menghadapi masalah yaitu tanggung jawab pers yang merupakan masalah klasik yang sampai saat ini terus dibicarakan. Tidak mudah memahami esensi kebebasan pers oleh karena masyarakat pers sering terjebak pemikiran seakan-akan kebebasan itu serta merta melekat pada profesi pers dan ancaman terhadapnya adalah ancaman profesi saja. Seperti belakangan misalnya sering muncul komentar, gugatan di pengadilan terhadap beberapa media massa di Indonesia adalah ancaman terhadap "pers nasional"

Pers sebenarnya hanya pihak yang mendapatkan kebebasan karena pers membawa kepercayaan masyarakat. Kebebasan pers instrument dari kebebasan masyarakat secara terorganisasi menyampaikan informasi. Dengan lahirnya UU No. 40 Tahun 1999 tentang pers (UU Pers). "kebebasan pers seperti kebablasan oleh karena undang-undang ini dianggap undang-

undang pers yang paling bebas di dunia, sehingga wartawan kita, merasa dirinya paling hebat, paling benar, dan paling dibutuhkan negara.
Bahkan ada kesan wartawan tak tersentuh hukum."1

Semua merupakan akses negative dari eforia reformasi karena dalam alam reformasi, pers nasional kembali ke alam liberal yang menurut teori libertarian seperti ditulis Siebert (Four Theories of the Press), merasa berhak menikmati kebebasan mutlak, pokoknya apa saja menurut wartawan layak dipublikasikan, itulah berita. Maka, mutlak diberitakan kepada publik $^{2}$. Namun teori ini sudah usang karena kebebasan pers dan pertanggung jawaban sosial harus berjalan beriringan.

\section{B. Pertanggungjawaban Pers.}

Dalam pasal 1 ayat (1) UU Pers disebutkan bahwa :

Pers adalah lembaga sosial dan wahana komunikasi yang melaksanakan kegiatan jurnalistik meliputi mencari, memperoleh, memiliki, menyimpan, mengolah dan menyampaikan informasi baik gambar serta data dan grafik maupun dalam bentuk lainnya dengan menggunakan media cetak, media elektronik dan segala jenis saluran yang tersedia.

Menurut Oemar Seno Adjie yang dimaksud dengan pers adalah ${ }^{3}$ :

1. Pers dalam arti yang sempit mengandung penyiaran-penyiaran pikiran, gagasan ataupun beritaberita dengan jalan kata tertulis.

\footnotetext{
${ }^{1}$ Tjipta Lesmana, "Wartawan bukan profesi eksklusif", Jurnal Keadilan Vol. 3 No. 5 Tahun 2004 2lbid

${ }^{2}$ Ibid

${ }^{3}$ Oemar Seno Adji, Mass Media dan Hukum, Erlangga, Jakarta, 1990, h. 11
} 
2. Pers dalam arti luas memasukkan di dalamnya semua media mosso communication yang memancarkan pikiran dan perasaan seseorang

Menurut Jacob Oetama :

Pers Indonesia pada khususnya adalah sarana sosialisasi per excelentiam apa saja yang dilakukan lewat pers kemudian berubah wujudnya menjadi sosial: komunikasi pribadi menjadi komunikasi sosial, perkenalan pribadi menjadi pergaulan sosial, kritik pribadi menjadi kritik sosial dan peringatan pribadi menjadi kontrol sosial ${ }^{4}$.

- Pers sebagai sub sistem komunikasi mempunyai peranan yang khusus seperti yang tertuang dalam UU Pers Pasal 5 Yaitu "pers nasional berkewajiban memberitakan peristiwa dan opini dengan menghormati normanorma agama dan rasa kesusilaan masyarakat serta asas praduga tak bersalah." Pasal 6 UU

Pers menyebutkan peran pers adalah :

a. Memenuhi hak masyarakat untuk mengetahui

b. Menegakkan nilai-nilai dasar demokrasi, mendorong terwujudnya supremasi hukum, dan hak asasi manusia, serta menghormati kebhinekaan

c. Mengembangkan pendapat umum berdasarkan informasi yang tepat, akurat dan benar.

d. Melakukan pengawasan, kritik, koreksi dan saran terhadap hal-hal

\footnotetext{
${ }^{4}$ Jacob Oetama, Perspektif Pers Indonesia, LPES, Jakarta, 1989, h 1
}

yang berkaitan dengan
kepentingan umum.

e. Memperjuangkan keadilan dan kebenaran.

Tanggung jawab pers merupakan tugas atau kewajiban moral pers dalam melakukan fungsinya sebagai media informasi. Komisi kebebasan pers (commission on freedom of the press) menguraikan tanggung jawab pers antara lain :

a. Memberi laporan peristiwa sehari-hari secara jujur, luas, dan cermat dalam konteks yang memberi arti terhadap kejadian itu.

b. Pers harus menjadi forum pertukaran komentar dan kritik.

c. Menonjolkan keadaan yang tepat mengenai kelompok yang penting dalam masyarakat.

d. Bertanggung jawab terhadap penyajian dan penjelasan mengenai tujuan dan nilai-nilai masyarakat.

e. Pers harus memberikan akses penuhpadapengetahuan mutakhir 5 .

Dalam hukum pidana secara umum diterima pendapat bahwa adanya suatu peristiwa pidana harus ada 2 (dua) anasir yang dipenuhi yaitu :

a. Anasir melawan hukum (weder rechtelijk) yakni suatu kelakuan yang melawan hukum.

b. Anasir kesalahan (schuld in ruimezin) yakni seorang pembuat (dader) yang dapat dianggap

${ }^{5}$ Wisnu Basuki, Pers dan Penguasa, Pustaka Sinar Harapan, Jakarta, 1995, h 124 
bertanggung jawab atas

kelakuannya 6 .

Pertanggung jawaban pidana atau kesalahan menurut hukum pidana terdiri atas 3 (tiga) anasiranasir :

1. Toerekeningsvatbaarheid,

(kesadaran yang dapat dipertanggung jawabkan) dari pembuat.

2. Suatu sikap psychis pembuat berhubung dengan kelakuannya.

3. Tidak ada alasan yang rnenghapus pertanggungjawabanpidana pembuat anasir

(toerekenbaarheid) $^{7}$

Sehubungan dengan masalah pertanggung jawaban, dalam UU Pers dan dalam KUHP sampai sekarang terjadi dualisme. Dalam penjelasan Pasal 12 UU Pers dikatakan yang dimaksud dengan penanggung jawab adalah penanggung jawab perusahaan pers yang meliputi bidang usaha dan bidang redaksi. Itu berarti kalau ada sengketa hukum, atau tuntutan pidana dan gugatan perdata, maka yang

bertanggung jawab adalah penanggung jawab.

Prinsip pertanggung jawaban seperti ini bersifat fiktif karena bisa jadi diadili disidang pengadilan adalah orang yang tidak melakukan perbuatan pidana. Sedangkan KUHP menganut prinsip pertanggung jawaban personal atau individu, artinya siapa yang melakadkan perbuatan pidana dialah yang

bertanggung jawab Berarti pertanggung jawaban pidana itu tidak

\footnotetext{
${ }^{6}$ Adami Chazawi, Pelajaran Hukum Pidana I, Raja Grafindo Persada, 2002, h 86 ${ }^{7}$ Ibid
}

bisa dipindahkan, dialihkan atau disubstitusikan kepada orang lain.

Dengan demikian jelas ada perbedaan prinsip pertanggung jawaban hukum menurut UU Pers dan menurut KUHP. Dengan kata lain ada dualisme pertanggung jawaban pidana. Atas dasar itulah apabila ada pengaduan kepada pihak kepolisian atas pemberitaan pers, maka sesuai dengan

ketentuan Pasal 55 KUHP, pihak penyidik selalu melakukan penyelidikan untuk menentukan siapa yang menjadi pelaku. Tetapi mengacu pada ketentuan UU Pers maka kalau ada pengaduan, tidak bisa lain penanggung jawab yang harus dimintakan pertanggung jawabannya.

Sehubungan dengan

pertanggung jawaban pidana yang dilakukan pers dengan pertumbuhan surat kabar dan majalah, memungkinkan tindak pidana menista dengan tulisan semakin besar terjadi.

\section{Kebebasan Pers}

Pers nasional sebagai wahana komunikasi penyebar informasi, dan pembentuk opini harus melaksanakan asas, fungsi, hak, kewajiban, dan peranannya dengan sebaik-baiknya berdasarkan kemerdekaan pers yang professional, sehingga harus mendapat jaminan dan perlindungan hukum, serta bebas dari campur tangan dan paksaan dari manapun.

Pers saat ini sedang di persimpangan jalan. Antara kebebasan, solidaritas, dan kekuatiran bahkan ketakutan. Beberapa mass media diantaranya Kompas dan Tempo paling tidak pernah mewakili dunia pers untuk digugat oleh 
Texmaco dan Tommy Winata. Mereka dituduh menyiarkan berita bohong tanpa klarifikasi dengan obyek berita. Kasus ini menimbulkan dilema bagi pers sendiri. Di satu sisi pers dituntut tidak menggunakan kebebasannya secara sewenangwenang. Di lain pihak tuntutan

hukum bagi pers dirasakan "keterlaluan" dan tidak adil.

Dalam menghadapi kasus, insan pers tidak segan-segan datang ke pengadilan untuk melakukan demo dengan orasi jangan melakukan pemasungan pers, kriminalisasi pers, pers jangan dipenjara dan lain sebagainya. Kalau kita mau jujur UU Pers sama sekali tidak mengenal istilah kebebasan pers, tetapi menggunakan istilah "kemerdekaan pers" sebagaimana yang disebutkan di dalam pasal 2 yang berbunyi, "kemerdekaan pers adalah wujud kedaulatan rakyat yang berasaskan prinsip-prinsip demokrasi, keadilan, dan supremasi hukum". Ini artinya kemerdekaan pers dijalankan di dalam bingkai moral, etika, dan hukum sehingga kemerdekaan pers adalah kemerdekaan yang disertai dengan kesadaran akan pentingnya penegakan supremasi hukum yang dilaksanakan oleh pengadilan $^{8}$.

Kebebasan pers sebenarnya dikonsepkan melaui suatu konklusi dari ketentuan pasal 4 ayat (2) dan (3) UU Pers yang pada intinya menyatakan pers bebas dari tindakan pencegahan, pelanggaran, dan atau penekanan dalam upaya mencari,

\footnotetext{
${ }^{8}$ Amir Syamsudin, dalam tulisan di Harlan Kompas, 18 September 2004 dengan judul "Pers dan Pengadilan."
}

memperoleh dan menyebar luaskan gagasan dan informasi. Dengan demikian makna kemedekaan pers lebih luas dari makna kebebasan pers yang dipersepsikan oleh insan pers.

Wartawan dalam kegiatannya sebenarnya terikat pada UU Pers dan Kode Etik Jurnalistik. Ini sesuai dengan Pasal 7 ayat (2) UU Pers yang menyatakan bahwa wartawan harus memiliki dan menaati kode etik. Kode etik menyatakan bahwa wartawan tidak boleh membuat berita yang memfitnah dan tidak berimbang. Apalagi dalam penjelasan UU Pers disebutkan bahwa Pers harus menghormati HAM. Oleh sebab itu dalam menjalankan tugasnya pers harus professional, dan etika pers harus selalu dapat dikontrol oleh masyarakat. Bentuk control pers adalah jaminan hak jawab dan hak koreksi bagi orang yang dirugikan oleh pemberitaan. Menarik untuk dibahas apaka UU pers merupakan lex specialis dari KUH Pidana terutama dalam kasus pencemaran nama baik, penghinaan dan fitnah. Ada pendapat yang berbeda. Pertama pendapat Hinca Panjaitan dan Amir Efendi Siregar sebagai anggota Dewan pers mengatakan "UU Pers merupakan lex specialis dari KUHP. Artinya, mereka yang menjalankan tugas jurnalistik, tidak bisa dijerat dengan pasal pencemaran nama baik dalam KUHP 9 ." Secara hukum didasarkan pada pasal 50 KUHP yang menyebutkan barang siapa melakukan perbuatan untuk melaksanakan ketentuan undang-

\footnotetext{
${ }^{9}$ Diskusi dalam Law Colloqium 2004, tgl 28-29 Juli 2004
} 
undang, tidak dipidana. Pasal 3 UU Pers menyatakan fungsi pers nasional adalah melakukan kontrol sosial.

Tugas jurnalistik dianggap sebagai perintah undang-undang, maka jurnalis yang menjalankan tugasnya tidak bisa dipidana. Argumen lain pasal 310 KUHP yang menyatakan pencemaran nama baik bukan pencemaran nama baik bila dilakukan untuk kepentingan umum.

Pendapat kedua, Anwar Nono Makarim dan Amir Syamsudin :

"UU Pers bukan spesialis KUHP karena suatu perbuatan, baik direstui hukum, disuruh hukum, atau tidak dilarang hukum, harus dilakukan sesuai dengan peraturan yang ada, sesuai dengan kepatutan dan tidak boleh melanggar hak orang lain. Karena saat ini pasal-pasal

pencemaran nama baik dan penghinaan dalam KUHP masih berlaku, maka yang seharusnya dilakukan adalah mengubah KUHP, apalagi jika mengubah KUHP akan membawa kemaslahatan kepada seluruhbangsa Indonesia, ketimbang menyatakan UU Pers sebagai lex spesialis, yang hanya bermanfaat bagi kalangan pers saja. Alangkah tidak simpatiknya kalau. seandainya pers hanya memikirkan diri sendiri sehingga seandainya anggota pers melakukan sesuatu perbuatan yang bisa dihukum, ia kemudian boleh menggunakan hak jawab tapi kalau warga negara Indonesia yang lain melakukan, ia masuk penjara."

Menurut Bangir Manan :

"bahwa UU pers tidak memilki sanksi pidana sehingga tidak dapat menjadi lex spesialis dari KUHP dan penggunaan ketentuan-ketentuan
KUHP sangat dimungkinkan terhadap kebebasan pers karena ketentuan itu hanyalah sarana yang digunakan untuk secara limitatif melakukan pengujian terhadap proses bekerjanya pers.

Pengujian tersebut dapat dilakukan dengan menggunakan parameter tertentu sebagaimana yang diatur dalam "Convention on the Freedom of Information" misalnya pers tidak dapat dituntut oleh hukum pidana positif kecuali pers melakukan halhal seperti penghinaan (defamation), hasutan (incitement to violence and crime), mengutuk Tuhan (blasphemy), pornografi, berita bohong, mengganggu "national security" dan "public order" dan pernyataan yang menghambat jalannya peradilan (impede the fair administration of justice)."

Yang menarik adalah pertimbangan majelis hakim dalam putusan perkara pidana No. 1349/Pen.Pid/2007.PN.Jak sel antara Tabloid Investigasi, edisi XI/17-30 Agustus 2006 dengan gubernur Kepulauan Riau Ismeth Abdullah yaitu "penjelasan UU Pers menyebutkan bahwa sepanjang

pertanggungjawaban pidana, menganut ketentuan perundangundangan yang berlaku yang mengandung arti pembuat UU Pers tidak menginginkan agar UU Pers sebagai lex specialis menggantikan KUHP.

Berdasarkan keputusan MA No. 1608/K/Pid/2005, UU Pers bersifat prima art atau prevail sehingga harus didahulukan." 
Adapun dakwaan jaksa melanggar pasal 311 ayat (1) jo pasal 316 KUHP telah terbukti, hanya masalah apakah perbuatan terdakwa yang menistakan Ismeth Abdullah pada Tabloid Investigasi merupakan perbuatan melanggar hukum? "Untuk itu menurut majelis, berita seputar dugaan korupsi yang dilakukan Ismeth Abdullah telah sesuai dengan ketentuan UU Pers. Terdakwa juga telah memuat secara utuh hak jawab yang diajukan Ismeth Abdullah pada edisi berikutnya." Mengingat ketentuan UU Pers, Pers Indonesia dalam menjalankan tugasnya dilindungi hukum, maka perbuatan terdakwa terbukti berdasarkan KUHP, menjadi hilang sifat melawan hukumnya. Sehingga dakwaan menjadi terbukti ${ }^{10}$.

\section{Penutup}

Kebebasan pers merupakan hak pers untuk tidak disensor, tidak dibredel, tetapi bukanlah hak untuk tidak dituntut di pengadilan bila melakukan tindakan melangar hukum.

Tidak ada yang namanya kriminalisasi pers, tetapi hanyalah hukum pidana digunakan untuk pelanggaran pidana oleh pers. Hal itu wajar karena pers bekerja dibawah supremasi hukum sehingga bila pers menyalahgunakan (abuse of liberty) maka institusi hukum menjadi sarana untuk mengujinya.

\section{Daftar Pustaka}

\footnotetext{
${ }^{10}$ Forum, edisi No. 39/28 Jan-3 Feb 2008

Adami Chazawi, Pelajaran Hukum Pidana I, PT. Raja Grafindo Persada, 2002

Jakob Oetama, Perspektif Pers Indonesia, LPES, Jakarta 1989

Oemar Seno Adji, Mass Media dan Hukum, Erlangga, Jakarta 1990

Wishnu Basuki, Pers dan Penguasa, Pustaka Sinar Harapan, Jakarta 1995

Majalah:

Jurnal Keadilan Vol 3 No. 5 Tahun 2004

Forum Edisi No. 39 / 2 Januari - 3 Februari 2008

Makalah :

Diskusi Law Colloqium, 28-29 Juli 2004

Koran:

Harian Kompas 18 September 2004 